\title{
Processing of red ceramic using a fast-firing cycle
}

\section{(Processamento de cerâmica vermelha usando um ciclo de queima rápido)}

\author{
G. T. Saleiro, J. N. F. Holanda \\ Grupo de Materiais Cerâmicos/LAMAV-CCT, Universidade Estadual do Norte Fluminense Darcy Ribeiro \\ Av. Alberto Lamego 2000, Campos dos Goytacazes, RJ, Brazil 28013-602 \\ gisele-teixeira@oi.com.br,jose.holanda@pesquisador.cnpq.br
}

\begin{abstract}
This work reports on the processing of red ceramic for civil construction using fast-firing cycles. The firing cycle is an important variable in the processing of red ceramic materials, which contributes to a high consumption of energy. The red ceramic pieces were prepared by industrial extrusion and fired at firing temperatures varying from $700{ }^{\circ} \mathrm{C}$ to $1100{ }^{\circ} \mathrm{C}$ using different firing cycles (slow-firing cycle $-1^{\circ} \mathrm{C} / \mathrm{min}$ and fast-firing cycle $-10^{\circ} \mathrm{C} / \mathrm{min}$ and $20^{\circ} \mathrm{C} / \mathrm{min}$ ). The technological properties (linear shrinkage, water absorption, apparent porosity, apparent density, and flexural strength) as function of the firing temperature and firing cycle are investigated. The development of the microstructure was followed by SEM/SEI. The results showed that fast-firing red ceramics exhibits technological properties and microstructure comparable to conventionally fired red ceramics, resulting in great advantages in energy saving.
\end{abstract}

Keywords: red ceramic, fast-firing, firing cycle, processing, properties.

Resumo

Este trabalho descreve o processamento de cerâmica vermelha para construção civil usando ciclos de queima rápido. O ciclo de queima é uma variável importante no processamento de materiais de cerâmica vermelha, o qual contribui para um alto consumo de energia. As peças de cerâmica vermelha foram preparadas por extrusão industrial e queimadas nas temperaturas de queima variando de $700{ }^{\circ} \mathrm{C}$ a $1100{ }^{\circ} \mathrm{C}$ utilizando diferentes ciclos de queima (ciclo de queima lento - $\quad 1{ }^{\circ} \mathrm{C} /$ min e ciclos de queima rápidos $-10^{\circ} \mathrm{C} /$ min e $20^{\circ} \mathrm{C} / \mathrm{min}$ ). As propriedades tecnológicas (retração linear, absorção de água, porosidade aparente, massa específica aparente e tensão de ruptura à flexão) em função da temperatura de queima e ciclo de queima são investigadas. O desenvolvimento da microestrutura foi avaliado por SEM/SEI. Os resultados mostraram que as peças de cerâmica vermelha obtidas via processo de queima rápida exibiram propriedades tecnológicas e microestrutura comparáveis àquelas convencionalmente obtidas via queima lenta, resultando em grande vantagem na economia de energia.

Palavras-chave: cerâmica vermelha, queima rápida, processamento, propriedades.

\section{INTRODUCTION}

The red ceramic industry is based mainly on the production of clayey ceramic materials for use in the civil construction such as bricks, ceramic blocks, roofing tiles and pipes [1]. Common clays are basically raw materials used for the manufacture of red ceramics. According with Dondi [2] the red ceramic processing is characterized by several manufacturing stages, including body preparation, shaping, drying and firing.

The main factors involved in the manufacturing process of red ceramics are the composition of raw materials and firing cycle (firing time and temperature). These factors fundamentally influence quality and cost of the final product. Slow-firing cycles are typically used for manufacture of red ceramic worldwide, which can reach up to $60 \mathrm{~h}$ (cold to cold), depending on the final product [2]. It is important to emphasize that the firing process is irreversible, and is responsible for final shape of the ceramic piece set in the stage of shaping of the clayey body. According with
Brindley [3] on firing the clay ceramic bodies undergo a complex series of physical-chemical reactions. It has been reported in the literature [4] that the main physical-chemical reactions of kaolinitic clays are: dehydroxylation of clay minerals, dehydration of hydroxides, phase transformations, and partial fusion with formation of a liquid phase at high temperature. The firing process of red ceramics, however, requires one high demand of energy.

Previous works have been devoted to the use of fastfiring technology for manufacture of several ceramic materials. Giuliano [5] reported on the use of fastfiring technology in the brick and tiles industries. It was demonstrated that the fast-firing technology presents high potential to optimize the firing process of ceramic materials for civil construction. The feasibility of fast-firing of pure alumina $\left(\mathrm{Al}_{2} \mathrm{O}_{3}\right)$ has been investigated [6]. It was found that the fast-firing approach can be used to manufacture alumina within very short production times at low temperature. Fast fired alumina exhibits mechanical performance nearly comparable to those of conventionally sintered alumina. 
The mechanical properties and microstructure of clay bricks obtained through slow traditional cycle ( $24 \mathrm{~h}$ cold to cold) and fast-firing cycles ( 3 - $5 \mathrm{~h}$ cold to cold) have been studied [7]. It was found that for clay bricks with equivalent water absorption, fast firing technique leads to higher flexural strength, lower apparent density, greater mean pore size, and improved frost resistance. The densification process of PZT type ceramics in fast firing approach has been described [8]. The densification behavior of PZT powder compacts was found to be influenced by the firing cycle, in which a maximum density of $98.5 \%$ was achieved for fast-fired compacts at $13500^{\circ} \mathrm{C} / 20 \mathrm{~min}$. It was found that all piezoelectric properties were improved by fast firing process compared to the conventional sintering. An important study [9] reported on the influence of the firing conditions $\left(2{ }^{\circ} \mathrm{C} / \mathrm{min}\right.$ (slow cycle) and $13{ }^{\circ} \mathrm{C} / \mathrm{min}$ (fast cycle)) on the technological properties of calcareous and non-calcareous clays. It was found that the water absorption and porosity values resulted to be higher, while linear shrinkage and flexural strength lower in the fast-fired clays. In terms of pore size distribution two contrasting trends were observed for calcareous clays (larger pores in fast firing) and for noncalcareous clays (vice versa). In addition, the slow-fired calcareous clay samples present a larger amount of newly formed phases (plagioclase, clinopyroxene, melilite) if compared with the fast-fired ones. The comparative analysis of the technological properties of red wall tiles produced using a traditional slow-firing cycle ( $24 \mathrm{~h}$ cold to cold) and fast-firing cycle ( $1 \mathrm{~h}$ cold to cold) have been also described [10]. It was concluded that the use of a slow-firing cycle resulted in enhanced properties of the red wall tiles. The effect of porcelain and glaze firing cycles on the fit of 3 types of all-ceramic crowns has been investigated [11]. It was found that porcelain firing cycle affected the marginal fit of the all-ceramic crowns. However, the glaze firing cycle had no significant effect on fit. Maciulaitis and Malaiskiene [12] reported on the feasibility to control quality of ceramics by changing the magnitudes of firing cycles. It was found a strong interdependence between the stages of firing cycles and structural parameters. In addition, it was also found that it is possible to select the firing cycles according to the desired structural parameters of a ceramic product. As can be observed, the fast-firing technology was successfully used for several ceramic materials. However, the validity of the fast-firing concept in the field of red ceramic is still subject to restrictions and requires much research and development work.

In this work is done a systematic study on the use of fast-firing cycles in the manufacture of red ceramic for civil construction, with special emphasis on the processing and technological properties of the fired pieces.

\section{MATERIALS AND METHODS}

The red clay body was collected from a red ceramic plant located in South-Eastern Brazil (Campos-RJ). The industrial clayey body is composed of a mixture of $70 \mathrm{wt} . \%$ of plastic clay and $30 \mathrm{wt} . \%$ of less plastic clay.

Mineralogical analysis of the red clay sample was done by X-ray diffraction (model XRD-700, Shimadzu), using monochromatic $\mathrm{Cu}-\mathrm{K} \alpha$ radiation over non-oriented specimens at a scanning speed of $1.5^{\circ}(2 \theta)$ per min. The crystalline phases were identified by comparing the intensities and positions of the Bragg peaks with those listed in the JCPDS-ICDD cards. The chemical composition of the clay sample was determined by X-ray fluorescence (XRF). The loss on ignition (LOI) was determined according to

$$
\mathrm{LOI}=(\mathrm{Wd}-\mathrm{Wc}) / \mathrm{Wd} \times 100
$$

in which $\mathrm{Wd}$ is the weight of the dry sample at $110{ }^{\circ} \mathrm{C}$, and $\mathrm{Wc}$ is the weight of the calcined sample at $1000^{\circ} \mathrm{C}$ during $1 \mathrm{~h}$.

The particle size analysis of the clay sample was done according to NBR 7181-84 [13]. The real particle density was determined according to NBR 6508-84 [14]. The plasticity was determined by the Atterberg method according to the NBR 6459-84 [15] and NBR 7180-84 [16] standardized procedures.

Thermogravimetric analysis (TGA and DrTGA) of clay sample was done within the $25-1150{ }^{\circ} \mathrm{C}$ temperature range using a heating rate of $10^{\circ} \mathrm{C} / \mathrm{min}$ under air atmosphere.

The ceramic pieces in the form of bars measuring $90 \mathrm{~mm} \times 35 \mathrm{~mm} \times 15 \mathrm{~mm}$ were prepared by industrial extrusion and then dried at $110{ }^{\circ} \mathrm{C}$ for $24 \mathrm{~h}$. Firing step was carried out at soaking temperatures varying from 700 to $1100{ }^{\circ} \mathrm{C}$ using different firing cycles $\left(1{ }^{\circ} \mathrm{C} / \mathrm{min}\right.$, $10{ }^{\circ} \mathrm{C} / \mathrm{min}$, and $20{ }^{\circ} \mathrm{C} / \mathrm{min}$ with $60 \mathrm{~min}$ soaking at the maximum temperature). For comparison, the firing cycle of $1{ }^{\circ} \mathrm{C} / \mathrm{min}$ was used as reference, because it corresponds to the traditional slow-firing cycle used in the red ceramic industry.

The following technological properties of the red ceramic pieces have been determined: linear shrinkage, water absorption, apparent porosity, apparent density, and flexural strength. Linear shrinkage values upon drying and firing were evaluated from the variation of the length of the rectangular bars. Water absorption was determined from weight differences between the as-fired and water saturated samples (immersed in boiling water for $2 \mathrm{~h}$ ). The apparent porosities of the pieces were determined by weighing them first dry in air, then heating them in boiling water for $2 \mathrm{~h}$ and finally, after cooling, weighing the now saturated pieces in both water and air. The apparent density was determined by the Archimedes method. The flexural strength $(\sigma)$ of the fired specimens was determined by the three-point bending test (model 5582, Instron) at a loading rate of $0.5 \mathrm{~mm} / \mathrm{min}$ according to

$$
\sigma=3 \mathrm{PL} / 2 \mathrm{bd}^{2}
$$

in which $\mathrm{P}$ is the load of rupture, $\mathrm{L}$ is the distance between supports, $\mathrm{b}$ the piece width, and $\mathrm{d}$ is its thickness. Microstructure characterization of fractured surfaces was carried out by scanning electron microscopy (model SSX- 
550, Shimadzu) via secondary electron images (SEI), at $15 \mathrm{kV}$, after gold coating.

\section{RESULTS AND DISCUSSION}

The first step of this investigation aimed the characterization of the industrial red clay body used. This is very important in order to understand the effects of the firing cycles on the processing and technological properties of red ceramics.

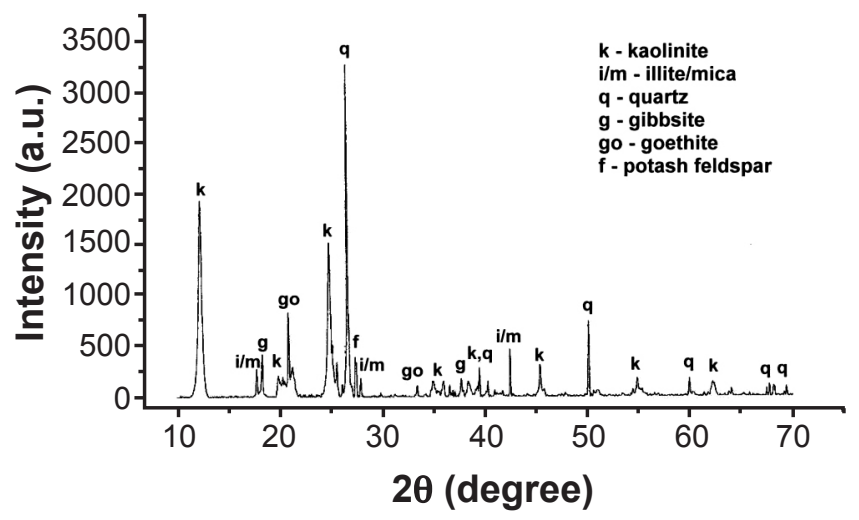

Figure 1: Typical X-ray diffraction pattern of the red clay sample. [Figura 1: Difratograma de raios $X$ da amostra de argila vermelha.]

The XRD pattern of the clay sample is shown in Fig. 1. The red clay has diffraction peaks predominantly associated with kaolinite $\left(\mathrm{Al}_{2} \mathrm{O}_{3} \cdot 2 \mathrm{SiO}_{2} \cdot 2 \mathrm{H}_{2} \mathrm{O}\right)$. Apart from the kaolinite phase, gibbsite $\left(\mathrm{Al}_{2}(\mathrm{OH})_{6}\right)$, goethite $\left(\mathrm{Fe}_{2} \mathrm{O}_{3} \cdot \mathrm{H}_{2} \mathrm{O}\right)$, quartz $\left(\mathrm{SiO}_{2}\right)$, potash feldspar $\left(\mathrm{KAlSi}_{3} \mathrm{O}_{8}\right)$, and illite/mica are detected by the XRD analysis.

Table I gives the chemical composition and loss on ignition of the red clay sample. The clay powder is composed mainly of $\mathrm{SiO}_{2}$ and $\mathrm{Al}_{2} \mathrm{O}_{3}$, which correspond to about 72.46 wt.\%. This result confirms that the clay sample is mainly composed of kaolinite clay mineral. The silica $\left(\mathrm{SiO}_{2}\right)$ is present in the structure of the clay minerals as kaolinite and illite/mica, structure of potash feldspar, as well as free quartz

Table I - Chemical composition of the red clay used (wt. \%). [Tabela I - Composição química da argila vermelha usada (\% em peso).]

\begin{tabular}{|c|c|}
\hline $\mathrm{SiO}_{2}$ & 40.31 \\
\hline $\mathrm{Al}_{2} \mathrm{O}_{3}$ & 32.15 \\
\hline $\mathrm{Fe}_{2} \mathrm{O}_{3}$ & 10.83 \\
\hline $\mathrm{TiO}_{2}$ & 1.49 \\
\hline $\mathrm{CaO}$ & 0.32 \\
\hline $\mathrm{MgO}$ & 0.78 \\
\hline $\mathrm{K}_{2} \mathrm{O}$ & 2.37 \\
\hline $\mathrm{Na}_{2} \mathrm{O}$ & 0.62 \\
\hline $\mathrm{MnO}$ & 0.10 \\
\hline LOI & 11.03 \\
\hline
\end{tabular}

LOI = loss on ignition particles. The alumina $\left(\mathrm{Al}_{2} \mathrm{O}_{3}\right)$ does not occur in its free form in the clay powder, being bounded to the clay minerals and gibbsite, as observed in Fig. 1. The amount of flux materials $\left(\mathrm{K}_{2} \mathrm{O}, \mathrm{Na}_{2} \mathrm{O}, \mathrm{CaO}\right.$ and $\left.\mathrm{MgO}\right)$ is low, except $\mathrm{Fe}_{2} \mathrm{O}_{3}$. The high iron oxide content would be responsible for the reddish color of the red ceramic pieces after firing. The loss on ignition (LOI) is relatively high $(11.03 \%)$, and is associated with the presence of clay minerals, hydroxides and organic matter.

Table II gives the relevant physical characteristics of the clay sample. It was verified that the clay sample presented reddish color, which is due to the high content of iron oxide (Table I). The real density obtained of $2.67 \mathrm{~g} / \mathrm{cm}^{3}$ reflects its mineralogical analysis (Fig. 1), and is typical of clayey materials. The clay powder sample presented a wide range of particle sizes ( 1 to $500 \mu \mathrm{m}$ ), where the major size ranges are clay $(<2 \mu \mathrm{m})$ with $31 \%$, silt $(2 \leq \mathrm{x}<63 \mu \mathrm{m})$ with $55 \%$, and sand $(>63 \mu \mathrm{m})$ with $14 \%$. When plotted in the Winkler diagram [17], the red clay sample is placed inside of the characteristic field for roofing tiles (field B). The plasticity of the clay sample was evaluated by the Atterberg's consistency limits [18]. The values of plasticity for the clay sample are within the acceptable range to industrial processing of red

Table II - Physical characteristics of the red clay sample. [Tabela II - Características físicas da amostra de argila vermelha.]

\begin{tabular}{lc}
\hline Characteristic & Range \\
\hline Color & Redish \\
Real density $\left(\mathrm{g} / \mathrm{cm}^{3}\right)$ & 2.67 \\
Clay $(\%)$ & 31 \\
Silt $(\%)$ & 55 \\
Sand (\%) & 14 \\
Liquid Limit (\%) & 65.2 \\
Plastic Limit (\%) & 27.5 \\
Plastic Index & 37.7 \\
\hline
\end{tabular}

ceramics. In terms of soil mechanics, the clay body sample may be classified as belonging to the group of high plasticity inorganic clays [19].

The thermogravimetric (TGA and DrTGA) curves for the red clay sample is shown in Fig. 2. Three endothermic events are seen in the DrTGA curve, which are related mainly to the evolution of the physically adsorbed water, dehydration of hydroxides, and dehydroxylation of clay minerals. The endothermic events correspond to an intense process of mass transfer in the sample as observed in the TGA curve. The sample presented a total weight loss during heating around $16.50 \%$. The thermogravimetry (TGA and DrTGA) of the sample confirms the kaolinitic nature of the red clay (dehydroxylation of kaolinite at $543.43{ }^{\circ} \mathrm{C}$ ) and presence of hydroxides as gibbsite and goethite (dehydration of hydroxides at $293.99^{\circ} \mathrm{C}$ ).

The technological properties of the ceramic pieces were measured upon drying at $110{ }^{\circ} \mathrm{C}$ (Table III). The linear shrinkage of the red ceramic pieces obtained by extrusion is of $4.53 \%$, which is within the optimal range 


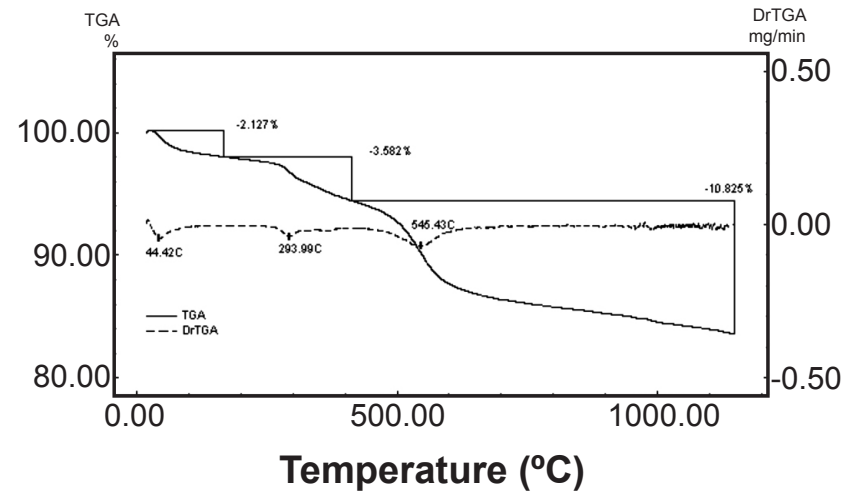

Figure 2: Thermogravimetric and differential thermogravimetric curves for the clay sample.

[Figura 2: Curvas termogravimétrica e derivativa termogravimétrica para a amostra de argila.]

to red ceramic processing [2]. The pieces presented apparent density of $1.62 \mathrm{~g} / \mathrm{cm}^{3}$. In the dried state the pieces presented high flexural strength (3.34 MPa), which satisfy the recommended industrial limits.

The technological properties of the red ceramic pieces

Table III - Technological properties of the red ceramic pieces in the dried state at $110^{\circ} \mathrm{C}$.

[Tabela III - Propriedades tecnológicas das peças de cerâmica vermelha secadas a $\left.110^{\circ} \mathrm{C}.\right]$

\begin{tabular}{ccc}
\hline $\begin{array}{c}\text { Linear } \\
\text { shrinkage } \\
(\%)\end{array}$ & $\begin{array}{c}\text { Apparent } \\
\text { density } \\
\left(\mathrm{g} / \mathrm{cm}^{3}\right)\end{array}$ & $\begin{array}{c}\text { Flexural } \\
\text { strength } \\
(\mathrm{MPa})\end{array}$ \\
\hline $4.53 \pm 0.45$ & $1.62 \pm 0.04$ & $3.34 \pm 0.74$ \\
\hline
\end{tabular}

obtained with different firing cycles between $700{ }^{\circ} \mathrm{C}$ and $1100{ }^{\circ} \mathrm{C}$, are shown in Figs. 3-7. All technological properties showed the dependence on the firing temperature.

The linear shrinkage of the red ceramic pieces is shown in Fig. 3. This property is related to the degree of densification during sintering, and is very important for the dimensional control of the finished red ceramic products. It can be observed that the shrinkage increases with the increase of the firing temperature. No significant change was found in linear shrinkage of the pieces $(0.62$ to 1.91 $\%$ ) between $700{ }^{\circ} \mathrm{C}$ and $900{ }^{\circ} \mathrm{C}$. The low shrinkage of the pieces observed in this temperature range is due the particles sintering be dominated by particle-to-particle contact mainly of metakaolinite particles. In this case, the sintering is dominated by solid state sintering mechanism [20]. Upon firing above $900{ }^{\circ} \mathrm{C}$, the shrinkage (2.49 to $9.65 \%$ ) continued to increase sharply with firing temperature. This is due the formation of a liquid phase, which aids the densification of the ceramic pieces, being viscous flow the dominant sintering mechanism.

No significant differences can be recognized in the linear shrinkage of the red ceramic pieces (Fig. 3) fired under different firing cycles. However, the results show small but important differences. For firing temperatures below

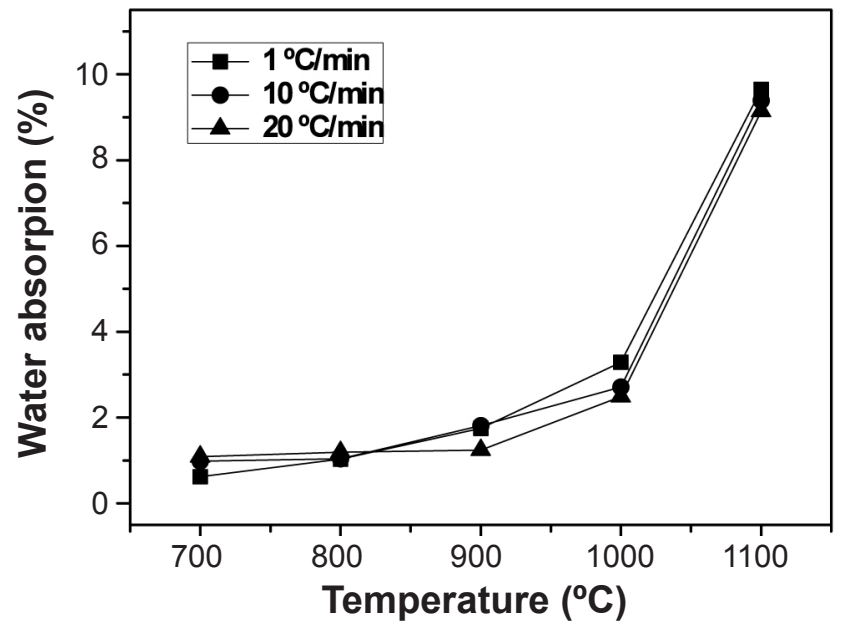

Figure 3: Linear shrinkage as a function of the firing cycle for all temperatures.

[Figura 3: Retração linear em função do ciclo de queima para todas as temperaturas.]

$900{ }^{\circ} \mathrm{C}$ the linear shrinkage of the ceramic pieces tends to lightly increase for fast-firing cycles $\left(10^{\circ} \mathrm{C} / \mathrm{min}\right.$ and $20{ }^{\circ} \mathrm{C} /$ $\mathrm{min}$ ). This behavior can be attributed to the higher amount of amorphous phase in this temperature range. In fact, the red clay sample is rich in kaolinite (see Fig. 1), which is transformed for amorphous metakaolinite around $543.43{ }^{\circ} \mathrm{C}$ (see Fig. 2). Above $900{ }^{\circ} \mathrm{C}$, however, the linear shrinkage tends to decrease for fast-firing cycles. This finding is likely related to the formation of new crystalline phases from metakaolinite such as 2:1 mullite or Si-containing $\gamma-\mathrm{Al}_{2} \mathrm{O}_{3}$ (Souza et al., 2003). Vitrification should be in progress in this temperature range. These circumstances are naturally connected with the lesser time available for physicalchemical reactions in the fast-firing cycles.

The water absorption of the red ceramic pieces is shown in Fig. 4. The water absorption is related directly to microstructure, and determines the open porosity level of the

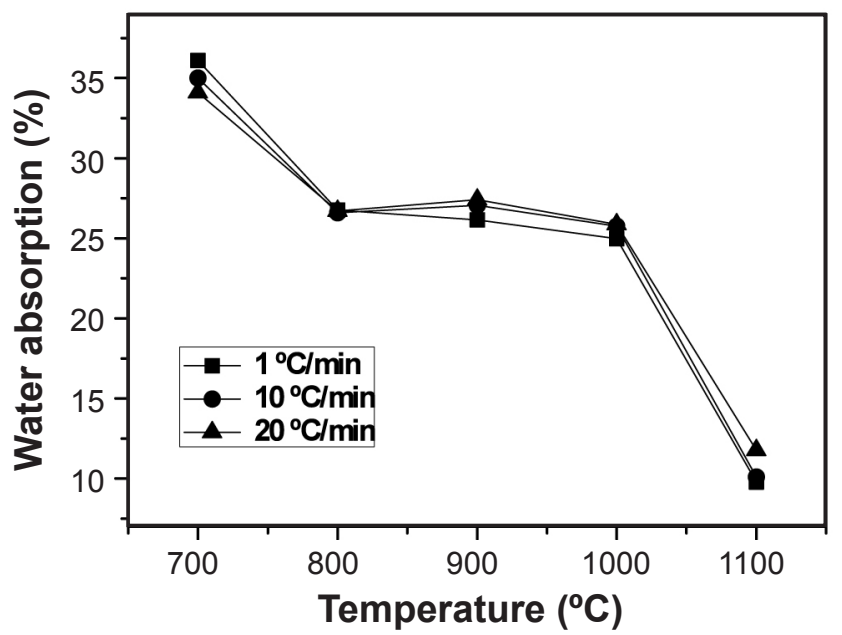

Figure 4: Water absorption as a function of the firing cycle for all temperatures.

[Figura 4: Absorção de água em função do ciclo de queima para todas as temperaturas.] 


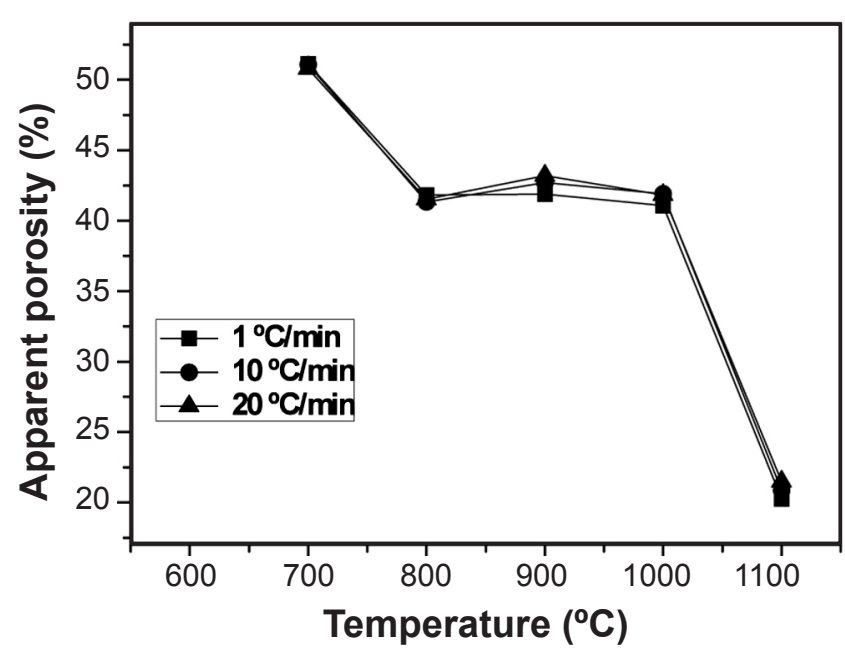

Figure 5: Apparent porosity as a function of the firing cycle for all temperatures.

[Figura 5: Porosidade aparente em função do ciclo de queima para todas as temperaturas.]

ceramic pieces. The open porosity affects several properties, such as mechanical strength, thermal and acoustic insulation capacity, frost resistance and permeability. As expected, the water absorption decrease with the increase of the firing temperature independently of the firing cycle. Sintering of the ceramic pieces accelerates above $900{ }^{\circ} \mathrm{C}$ as the glassy phase is formed. This phase penetrates the open pores, closing then and isolating neighboring pores. This explains the intense decrease of the water absorption in higher firing temperatures. On the other hand, no significant change was found in the water absorption of the red ceramic pieces fired under different firing cycles. This is in accordance with the apparent porosity values (Fig. 5). However, in a similar way to the shrinkage values, again, small differences can be observed. In general, the water absorption and apparent porosity values were observed to increase slightly for fastfiring cycles mainly for $20^{\circ} \mathrm{C} / \mathrm{min}$.

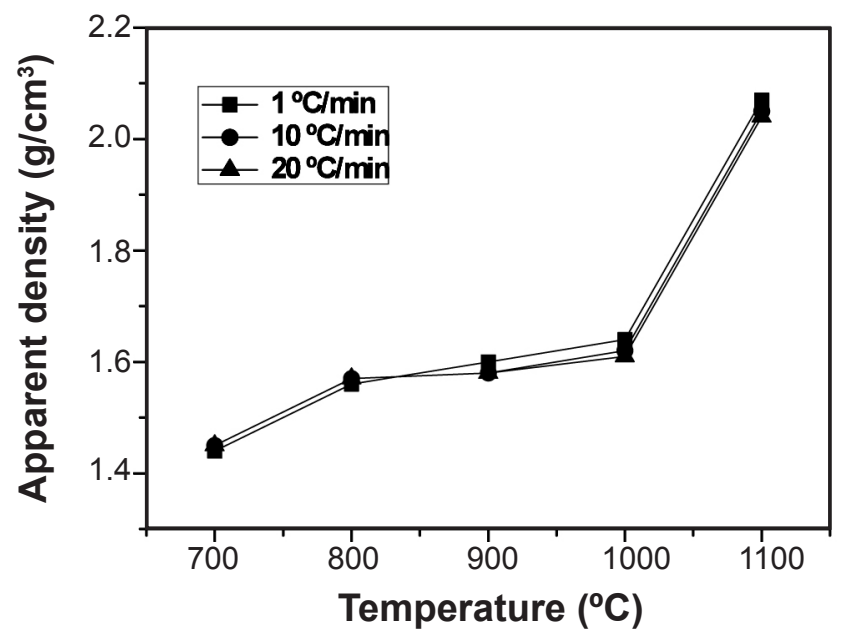

Figure 6: Apparent density as a function of the firing cycle for all temperatures.

[Figura 6: Massa específica aparente em função do ciclo de queima para todas as temperaturas.]

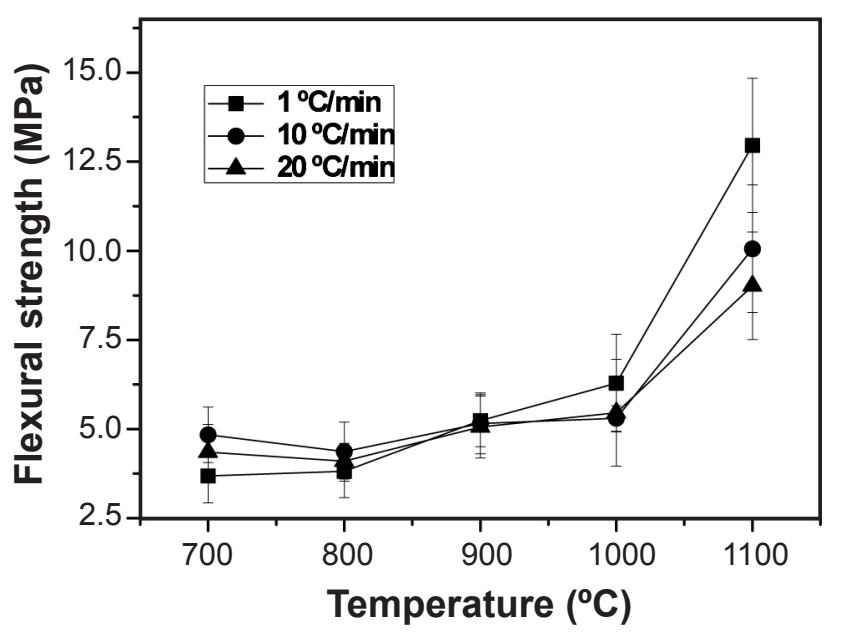

Figure 7: Flexural strength as a function of the firing cycle for all temperatures.

[Figura 7: Tensão de ruptura a flexão em função do ciclo de queima para todas as temperaturas.]

The apparent density of the ceramic pieces is shown in Fig. 6. It can be observed that the apparent density increases with the increase of the firing temperature, being more significant above $900{ }^{\circ} \mathrm{C}$ independently of the firing cycle. This behavior can be attributed to the vitrification that helps to reduce the open porosity, resulting in denser red ceramic pieces. The apparent density of the pieces, as shown in Fig. 6, presented only slight differences with the firing cycles. Comparing the different firing cycles, the apparent density values resulted to be slightly lower in the fast-firing red ceramics.

The flexural strength of the fired pieces as a function of firing temperature and firing cycle is shown in Fig. 7. The effect of the firing temperature was to increase the flexural strength of the pieces by means of densification, and reached their maximum values at $1100{ }^{\circ} \mathrm{C}$. The correlation between flexural strength and physical properties (linear shrinkage, water absorption, apparent porosity and apparent density) of the red ceramic pieces is well established. In general, the flexural strength values resulted to be slightly lower in the fast-firing red ceramics. It can be also observed in Fig. 7 the effect of the firing cycle with respect to mechanical strength. For firing temperatures up to $1000{ }^{\circ} \mathrm{C}$, the flexural strength values resulted to be only slightly lower in the fast-firing red ceramics. At $1100{ }^{\circ} \mathrm{C}$, however, a tendency toward lower flexural strength in the fast-firing red ceramics is observed. This behavior is related to the formation of microcracks in the sintered matrix during cooling due to the phase transformation $\beta-\alpha$ of the quartz particles. Despite this, all ceramic pieces fired at $1100{ }^{\circ} \mathrm{C}$ met the requirements of mechanical strength for red ceramic predicted by the Brazilian standard specification. This result is very important, because it demonstrates the possibility of great economy of energy during red ceramic processing with only small sacrifice of the technological properties.

In order to enlighten the densification behavior on firing, the fracture surface of the as-fired red ceramic pieces were examined (Fig. 8a - c). The micrographs show the evolution 

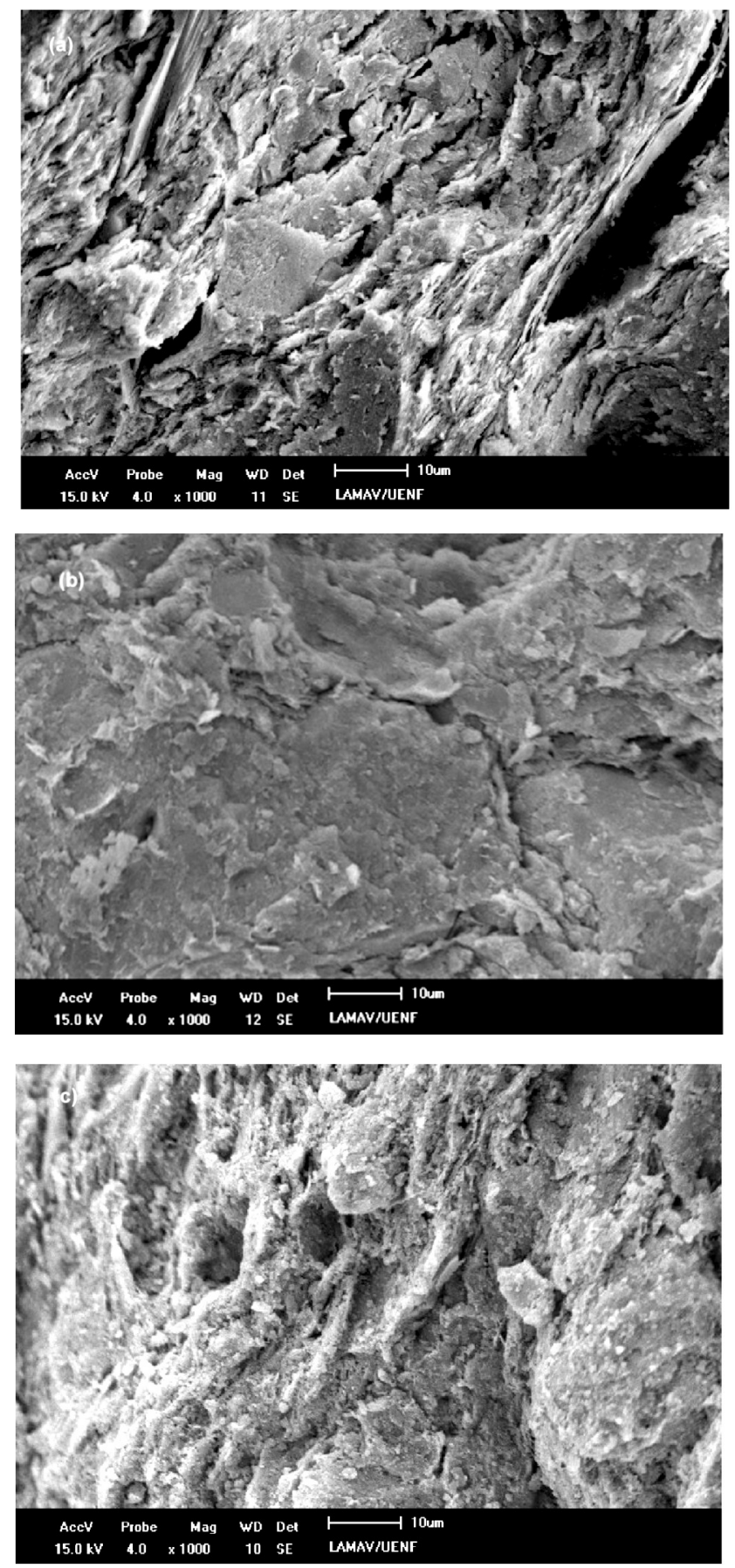

Figure 8: Microstructure of red ceramic fired at $1000{ }^{\circ} \mathrm{C}$ at different firing cycles: (a) $1{ }^{\circ} \mathrm{C} / \mathrm{min}$ (slow-cycle); (b) $10^{\circ} \mathrm{C} / \mathrm{min}$; and (c) $20^{\circ} \mathrm{C} / \mathrm{min}$.

[Figura 8: Microestrutura de cerâmica vermelha queimada a $1000{ }^{\circ} \mathrm{C} \mathrm{em}$ diferentes ciclos de queima: (a) $1{ }^{\circ} \mathrm{C} / \mathrm{min}$ (ciclo de queima lento); (b) $10^{\circ} \mathrm{C} / \mathrm{min} ; e(c) 20^{\circ} \mathrm{C} / \mathrm{min}$.]

of the structure of the red ceramic fired at $1000{ }^{\circ} \mathrm{C}$ with firing cycle. The SEM images of the fracture surface of all pieces reveal the agglomeration of clay particles of varying size and shape, microscopic pores and voids. This signifies that the slow-fired pieces had a microstructure similar to that of fast-firing ceramic pieces. This clearly shows that the use of fast-firing cycles in the red ceramic processing does not cause significant modification on the texture and porosity of the fired pieces. These results are in accordance with the technological properties.

\section{CONCLUSIONS}

The experimental results showed clearly that the use of fast-firing cycles (shorter time) seems to be an important approach in the red ceramic processing, resulting in energy saving. The performance of the technological properties of the fast-firing red ceramic pieces between 700 and $1100{ }^{\circ} \mathrm{C}$ is, in first approximation, comparable to conventionally fired red ceramics, except the flexural strength at $1100^{\circ} \mathrm{C}$. The use of fast-firing cycles does not cause significant modification on the microstructure and porosity of the red ceramic pieces. In the context of the manufacture of red ceramic products, it is apparent from obtained results that the use of fastfiring technology is viable technically and economically. In addition, the fast-firing technology can be easily adapted to the red ceramic industrial processing.

\section{ACKNOWLEDGMENTS}

To CNPq, FAPERJ and CAPES for financial support, and the São José Industry by the supply of the red clay body.

\section{REFERENCES}

[1] P. S. Santos, Ciência e Tecnologia de Argilas, Vol. 1, $2^{\mathrm{a}}$ Ed., Edgard Blücher Ltda., S. Paulo, SP (1989).

[2] M. Dondi, Int. Ceram. J. (2003) 55-59.

[3] G. W. Brindley, Cerâmica 42 (1978) 217-224.

[4] G. P. Souza, R. Sánchez, J. N. F. Holanda, J. Therm. Anal. Calorim. 73 (2003) 293-305.

[5] E. Giuliano, Ziegel. Int. 46 (1993) 168.

[6] D. E. García, J. Seidel, R. Janssen, N. Clanssen, J. Eur. Ceram. Soc. 15 (1995) 935-938.

[7] M. Dondi, M. Marsigli, I. Venturi, Brit. Ceram. Trans. 98 (1999) 12-18.

[8] C. Miclea, L. Tanasaiu, C. F. Miclea, L. Amarande, R. Iorgulescu, V. Tanasaiu, S. Moscu, J. Optoelec, Adv. Mater. 3 (2001) 83-87.

[9] M. I. Carretero, M. Dondi, B. Fabbri, M. Raimondo, Appl. Clay Sci. 20 (2002) 301-306.

[10] M. F. Pinto, S. J. G. Sousa, J. N. F. Holanda, Cerâmica 51, 319 (2005) 225-229.

[11] M.C. Balkaya, A. Cinar, S. Pamuk, J. Prost. Dent. 93 (2005) 346-355.

[12] R. Maciulaitis, J. Malaiskiene, Const. Build. Mater. 23 (2009) 226-232.

[13] NBR 7181-84, Soil: Granulometric Analysis, ABNT (1984).

[14] NBR 6508-84, Soil: Real Specific Mass, ABNT (1984). [15] NBR 6459-84, Soil: Determination of the Liquid Limit, ABNT (1984).

[16] NBR 7180-84, Soil: Determination of the Plastic Limit, ABNT (1984). 
[17] S. Pracidelli, F.G. Melchiades, Ceram. Ind. 2 (1997) 31-35.

[18] C. F. Gomes, Argilas - O Que São e Para Que Servem, Fundação Calouste Gulbenkian, Lisboa, Portugal (1988).
[19] H. P. Caputo, Mecânica dos Solos e Suas Aplicações Fundamentais, Livros Técnicos, Rio de Janeiro, RJ (1994). [20] F. A. C. Milheiro, M. N. Freire, A. G. P. Silva, J. N. F. Holanda, Ceram. Int. 31 (2005) 757-763.

(Rec.23/05/2011, Rev.06/12/2011, Ac. 10/01/2012) 